\title{
Preserving tropical soil organic matter at watershed level. A possible contribution of urban organic wastes
}

\author{
Claudia Binder ${ }^{1,3, *} \&$ Nikola Patzel ${ }^{2}$ \\ ${ }^{1}$ Department of Environmental Sciences, Chair of Resource and Waste Management, ETH Zürich, CH-8600 \\ Dübendorf, Switzerland; ${ }^{2}$ Department of Environmental Sciences, Chair of Resource and Waste Management, \\ ETH Zürich and EAWAG, CH-8600 Dübendorf, Switzerland; ${ }^{3}$ Department of Environmental Sciences: Natural \\ and Social Science Interface, ETH-Zentrum, HAD G16, Haldenbachstrasse 44, CH- 8092 Zürich, Switzerland; \\ *Author for correspondence (e-mail: binder@uns.umnw.ethz.ch)
}

Received 25 October 1999; accepted in revised form 8 February 2001

Key words: cambisols, material flux analysis, soil organic matter, tropics, urban organic wastes, watershed

\begin{abstract}
The goal of this paper is to put the issue of preserving Soil Organic Matter (SOM) into a regional, urban-rural, context. In doing so, we apply the method of material flux analysis to a watershed in Boyacá in Colombia. We estimate the order of magnitude of the dry organic matter and carbon fluxes between the rural and urban parts of the region, including estimates on biomass growth, tillage, organic waste, and sewage. These estimates are used to derive potentials for carbon cycling between rural and urban areas. It is shown that (i) for the municipality of Tunja, the treated organic wastes produced in the urban area could add about $30 \%$ to the current carbon input into arable soils; (ii) to preserve the organic carbon content in soils in Tunja over the long-term, either, erosion control measures have to be implemented and/or the total treated urban organic wastes have to be concentrated on about $1 / 5$ of the agricultural area. However, such an attempt has to consider the possible trade off between allocation needs (poor farmers on the hillside) and allocation costs (transportation and distribution costs).
\end{abstract}

\section{Introduction}

Bormann and Likens (1969) first performed quantitative ecological analyses at watershed level. With their famous Hubbart Brook experiment, they further developed the concept of Lindeman (1942) and Odum (1955) which analyzes an ecosystem as a series of compartments, which are linked by measurable energy and nutrient fluxes.

This way of thinking is now an accepted and often-used approach to analyze sustainable resource management. That is, in systems where human settlements play an important role, rural-urban interactions become relevant for the analysis. Throughout history, these interactions and their concepts have changed significantly. Von Thünen (1826), an agricultural economist, was a pioneer in conceptualizing these interactions. He envisaged an isolated town supplied by farmers from the surrounding countryside and mod- elled this as a ring-like stratification of land use around the city. His economic parameters were earnings per hectare, cost of manufactured goods from the city, transport cost, and land and labor intensities of crops (Samuelson, 1987).

Taking this model of rural-urban interaction as being bi-directional, one could consider that the urban center would supply the surrounding rural areas with its wastes. That is, in the cities, the liquid and solid wastes were collected, sometimes treated, and transported to the rural areas, where they were used as fertilizers. That was done by the Incas in Peru who dried their excreta and used them as fertilizer in powder form (Graff, 1995). Nowadays, this practice is used in peri-urban areas in China and Vietnam. There, farmers in the peri-urban area supply some urban sectors with food. Their inhabitants deliver at the beginning of the crop growing season their night soil (including faece, urine and ablution water; Cross and Strauss, 1985) to 
the peri-urban farmers, who apply it to their fields, supplying the soil with nutrients and organic carbon (Cross and Strauss, 1985).

These practices may be seen as residuals from premodern agriculture. However, in the last two decades they have been objects of growing interest, because of waste treatment and soil fertility problems both. Research topics refer to:

- Treatment of organic wastes in order to reduce their health and environmental impacts (Shuval et al., 1981; Cross and Strauss, 1985; Obeng and Wright, 1987).

- Effects of incorporation of treated organic wastes into soils, i.e. (i) changes in soil organic carbon content (Khaleel et al., 1981); (ii) changes in the physical structure of the soil (Pagliai and Antisari, 1993); (iii) fertilizing effect of organic wastes (Shuval et al., 1981); and (iv) changes in the content of heavy metals in the soil (Baccini and von Steiger, 1993).

- Costs and logistics for collecting and treating urban organic wastes (Shuval et al., 1981).

Even though the use of organic wastes in agriculture involves the link to urban areas, no studies have explicitly analyzed the potential fluxes of organic carbon and nutrients from urban to rural areas at regional level. We want to contribute to filling this gap. We apply the method of material flux analysis (MFA; Baccini and Bader, 1996), to model possible contributions of a whole rural-urban region for preserving SOM. We analyze the fluxes of organic carbon between the urban and the rural areas, taking the watershed within the municipality of Tunja in Colombia as a case study. We present the main dry organic matter and organic carbon fluxes and derive the potential for organic carbon recycling. The questions addressed are:

- How large are the organic waste fluxes generated in the urban and rural areas of Tunja?

- What is the potential of organic waste products for preserving SOM?

\section{Study area}

\section{General characteristics}

Tunja is the capital of the Departamento de Boyacá in Colombia. It is located in the eastern chain of the Andes at an altitude of $2800 \mathrm{~m}$ above sea level. It has an area of $117 \mathrm{~km}^{2}$ and a population of 114,000 (DANE, 1994). The region lies in a valley, which is
$15 \mathrm{~km}$ long, $4.5 \mathrm{~km}$ wide and slopes with an inclination of $1 / 100$ in northerly direction. The urban area is located at the bottom of the valley and covers about $9 \%$ of the area, holding $95 \%$ of its inhabitants. The watershed within the municipality covers about $90 \%$ of the municipal area. Half the rural population lives in scattered houses, half in small villages. Due to its altitude, and geographical location, average temperature in the region is $13{ }^{\circ} \mathrm{C}$, with an average night-time temperature of $5{ }^{\circ} \mathrm{C}$ and an average day-time temperature of $20{ }^{\circ} \mathrm{C}$. It is a relatively dry region with an average precipitation of $600 \mathrm{~mm}$ per year in two wet seasons.

\section{Soils of the region}

The soils in Tunja are post-glacial developing soils with good fertility, if not degraded. These soils are rather young, compared to other tropical soils. The parent materials are mostly siliceous fluvio-glacial sediments, with some additions of volcanic flue ash. In the deeper layers, dense fossil red soils are found. The top-soils mostly belong to the cambisols (US: inceptisols), the remainder consists of fluvisols (entisols), lixisols (alfisols) and andosols (andisols). About $95 \%$ of the area in rural Tunja is affected by erosion (Table 1).

Soil texture is mostly sandy loam, in some places sandy clay loam. Soil organic matter, $( \pm 1 \%)$ and $\mathrm{N}_{\text {org }}$ $( \pm 1 \%$ o contents are at the lower boundary of the observable range for this soil type (Haase, 1992; Anjos et al., 1998). As under a relatively cold temperature regime (alt. $2800 \mathrm{~m}$ ) SOM content is similar to that in untilled Bolivian cambisols in a warm climate (alt. $200 \mathrm{~m}$; Haase, 1992), it seems likely that SOM losses have taken place at the Tunja site. Soil depth in the slightly eroded and uneroded parts (12\%) is about $1 \mathrm{~m}$, in the slightly to moderately eroded parts $(84 \%)$ about $0.5 \mathrm{~m}$ and in the severely eroded patches $(4 \%)$ it is reduced to $15 \mathrm{~cm}$. Bulk density is low to moderate $\left(0.5-1.3 \mathrm{t} \mathrm{per}^{3}\right)$ in the A-horizon, and high in the subsoil $\left(2 \mathrm{t}_{\text {per }} \mathrm{m}^{3}\right)$. Cation exchange capacity (CEC) is on average $8 \mathrm{cmol}$ per $\mathrm{kg}$.

\section{Land use and ownership structure}

Land use in rural Tunja consists of pasture for meat and milk production (about 41\%), arable farming (about 40\%), urban area (9\%) and other land uses including forests and unproductive areas (Table 2). The arable crops are potatoes, wheat, oats, maize and 
Table 1. Incidence of erosion in Tunja and the central region of Boyacá (URPA, 1995) ${ }^{1}$

\begin{tabular}{lccccc}
\hline & $\begin{array}{c}\text { Not } \\
\text { eroded }\end{array}$ & $\begin{array}{c}\text { Light } \\
\text { erosion }\end{array}$ & $\begin{array}{c}\text { Light to } \\
\text { moderate } \\
\text { erosion }\end{array}$ & $\begin{array}{c}\text { Moderate } \\
\text { to severe } \\
\text { erosion }\end{array}$ & Total area \\
\hline Tunja area $\left(\mathrm{km}^{2}\right)$ & 6 & 8.6 & 98 & 4 & 117 \\
Tunja area $(\%)$ & 5 & 7 & 84 & 4 & 100 \\
Central Boyacá $\left(\mathrm{km}^{2}\right)$ & 390 & 1340 & 780 & 120 & 2630 \\
Central Boyacá $(\%)$ & 15 & 51 & 30 & 5 & 100 \\
\hline
\end{tabular}

${ }^{1}$ This study also considers areas in the urban part where soil can run off during the rainy season.

Table 2. Land use in Tunja in $\mathrm{km}^{2}$ (1994)

\begin{tabular}{llllll}
\hline Land use & Pasture & Arable land & Urban & Other uses & Total \\
\hline Area in $\mathrm{km}^{2}$ & 48 & 47 & 11 & 11 & 117 \\
\hline Source: Unidad Regional de Planificacion & Agropecuaria (URPA), \\
1995.
\end{tabular}

sorghum. Typical rotations in the area are: potatoespotatoes, potatoes-maize, potatoes-pasture, wheatpasture, and oats-pasture.

The agricultural sector is organized in minifundios that are small holdings of land of about 1-3 ha. According to URPA (1995), about $76 \%$ of the farmers in Tunja are smallholders with holdings smaller than 3 ha, utilizing $22 \%$ of the total agricultural area. About $3 \%$ of the farmers own holdings larger than 20 ha and utilize over $36 \%$ of the total agricultural area.

\section{Waste management in Tunja}

Sanitation. Approximately $92 \%$ of the urban and 3\% of the rural population are connected to a sewer system. The sewage is discharged into the surface water without any treatment. Thus, the surface water leaving Tunja is heavily contaminated. Farmers downstream use this water for irrigating their pasture plots adjacent to the river (EAAT, 1993; DANE, 1994).

Waste management. About $70 \%$ of the population in urban Tunja is served with regular waste collection. The municipality produces about $0.33 \mathrm{~kg}$ fresh weight waste per capita per day, totaling 18,000 $\mathrm{t}$ per annum. Households produce around $80 \%$ of the total waste (Gorraiz, 1988). The waste is collected on a dumping site and irregularly covered with soil. Seventythree percent (fresh weight) of the waste generated by households is organic material.
Currently no efforts are made to use these organic wastes for producing compost and applying it to rural areas. Neither has it been considered to use excreta as a nutrient source in agriculture.

\section{Methods and data sources}

\section{Material flux analysis}

Material flux analysis (MFA) is a method to describe and analyze the material balances of a system, e.g., an industry or a region. A MFA model is defined by a system border, internal and external balance volumes ('processes'), goods or materials, and their fluxes between different processes. A 'material' is defined as an element or chemical compound (e.g., $\mathrm{P}$ or $\mathrm{CO}_{2}$ ), a 'good' is a compound forming a product (e.g., corn or compost). The transfer-coefficients define the fraction of the total input into a process 1 which is transferred from the process 1 into other processes (whereas: $\left.k_{12}+k_{13}+\ldots . .+k_{1 n}=1\right)$.

MFA is based on the law of conservation of matter and energy. It has been applied to analyze and model materials balances of corporations and urban regions in industrialized countries (Baccini and Brunner, 1991; Baccini and Bader, 1996), to estimate the balance of heavy metals and nutrients in agricultural soils (Baccini and von Steiger, 1993) and to describe agricultural systems in Switzerland (Müller et al., 1995). In developing countries it has been applied to an urban region in Colombia to study the water balance (Binder et al., 1997) and the consumption of goods and generation of waste (Binder, 1996).

\section{Estimation of SOM Losses}

Two processes mainly drive decreases in soil organic carbon: erosion and decomposition. 
For quantifying soil erosion we used previous estimates (Binder, 1996; Aliva Neira and Rincon Suarez, 1998). The estimates were based on runs with the model EPIC (Erosion Productivity Impact Calculator) which was adapted to the local conditions. The estimates were cross-checked with water quality measurements. The error range of these estimates lies at 30 to $40 \%$.

Decomposition of treated organic wastes on or in the soil was estimated on the basis of laboratory and field studies (e.g., Kirchmann and Bernal, 1997; Pascual et al., 1998). Their models, mostly using firstorder or first-zero-order kinetics, match the concept that there is one fraction, which decomposes rapidly and another one decomposing at slower rates.

\section{Data sources}

We used data from earlier analyses in the region (Binder, 1996) and from B.Sc. theses from students of the Fundación Universitaria de Boyacá (Alba Gonzales et al., 1998). In addition, we used regional statistical data (URPA, 1995). The results were crosschecked with data from literature (Brady and Weil, 1996). For soil data and waste analysis we used secondary data (Gorraiz, 1988; Binder 1996; Aliva Neira and Rincon Suarez, 1998).

\section{Material flux analyses of the rural and urban subsystems}

\section{State of the art of MFA's in tropical agriculture}

In recent years nutrient and carbon budgets and balances have received increasing attention in tropical agriculture. Geographically, the focus of these investigations has been sub-Saharan Africa, because the scientific (and the research funding) community was alerted by studies indicating dramatic losses of carbon and nutrients in African soils (Stoorvogel and Smaling, 1990). For a thorough review and critique of the MFA approach in tropical agriculture see Scoones and Toulmin (1998).

The majority of these studies was realized on farm and plot level. A classical balance-volume-approach to the farming system was followed by Lynam et. al (1998); nutrient balances have been analyzed by Sheperd and Soule (1998). Bosch (1998) combined the MFA analysis with mathematical modeling and economic data. The possible use of urban wastes to improve the rural carbon balance was mentioned by
Nandwa and Bekunda (1998). However, MFA has not been applied at regional level combining rural and urban fluxes.

\section{System analysis for the Municipality of Tunja}

We selected the political border of the Municipality of Tunja as the system border for our analysis. The system consists of two subsystems, rural Tunja and urban Tunja; it comprises a total of 9 processes and 21 goods. The urban sub-system includes the processes Market Place and Supermarket, which supply the city with food; Consumers that consume the food and dispose of the food residues (organic waste) in the Landfill, and have their excreta transported to the Surface Water (Figure 1). The rural sub-system includes two agricultural processes: Cattle Breeding/Milk Production and Plant Growth and Management (arable farming). Two separate soil compartments are distinguished: Pasture Soils and Arable Soils.

\section{Current situation}

Figure 2 presents the results of the MFA for dry matter (DM) for the year 1993.

Urban subsystem: Supermarket and Market Place supply $55 \%$ and $45 \%$ of the food respectively. About $50 \%$ of the total food demand of Tunja can be covered by local production, i.e., rural Tunja is able to satisfy the demand for tubers completely, for cereals for about $70 \%$ and for meat for about $30 \%$ (Binder, 1996). The remainder has to be imported, while surplus potatoes is exported. Tunja is a net importer of about $6500 \mathrm{t}$ DM per year, that is $27 \%$ of its total consumption.

In the process Consumers, most of the food is digested and respired $\left(20,300 \mathrm{t} \mathrm{DMyr}^{-1}\right)$. The organic waste produced by Consumers is deposited in the Landfill (3000 $\mathrm{t} \mathrm{DMyr}^{-1}$ ); excreta are transported without treatment to the Surface Water (1400 t $\mathrm{DMyr}^{-1}$ ). The Market Place generates $6 \%$ of the total solid organic waste generated in urban Tunja. The Landfill produces methane $\left(\mathrm{CH}_{4}\right), \mathrm{CO}_{2}$, and leachates.

Rural sub-system: The largest influx into the rural area is $\mathrm{CO}_{2}$ import for photosynthesis. In the process Plant Growth and Management, about 24,000 t dry matter are generated, of which about $73 \%$ become agricultural products traded in the Market Place. The other $27 \%$ comprises roots and plant residues. Carbohydrates exuded by roots are not taken into account. According to Alba Gonzales et al. (1998), 84\% of the surface residues are left on the soil and $16 \%$ are collec- 


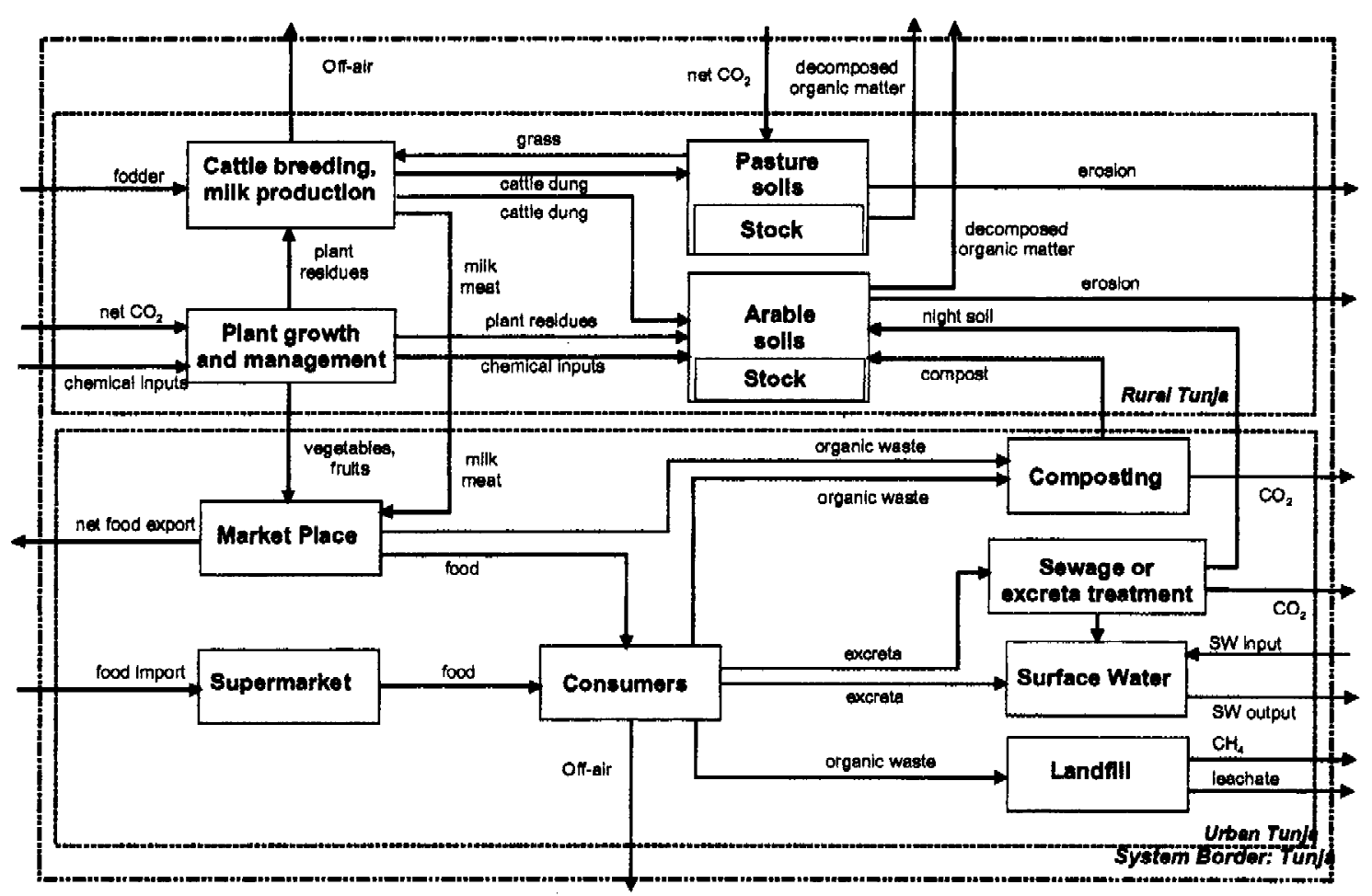

Figure 1. System analysis for the municipality of Tunja. Process: $\square$; Flux: -

ted for feeding the farm animals. For plant production (mostly potatoes), mineral fertilizer is imported.

Cattle production is sustained to a large extent by the pastures in rural Tunja. Fodder is imported to supplement cattle diet. Via cattle dung, some nutrients and carbon are returned to Pasture Soils and Arable Soils. According to Alba Gonzales et al. (1998), farmers collect about $44 \%$ of the cattle dung to use it on their arable fields. However, cattle dung with $190 \mathrm{t}$ $\mathrm{DMyr}^{-1}$ is only about $3 \%$ of the total input of organic dry matter into arable soils.

\section{Potential organic carbon sources}

There are two main potential sources of organic carbon to soils: crop residues including roots (6400 $\mathrm{t}^{\mathrm{DMyr}}{ }^{-1}$ ) and urban organic wastes (solid $3200 \mathrm{t}$ $\mathrm{DMyr}^{-1}$ and liquid $1400 \mathrm{t} \mathrm{DMyr}^{-1}$ ). In rural Tunja, about $84 \%$ of the plant residues are left on the field and plowed in during land preparation (Alba Gonzales et al., 1998).

For human health reasons, organic wastes from the urban area should be treated before they are applied to agricultural soils (Cross and Strauss, 1985). Thus, for our calculations we assumed that solid organic wastes, i.e., food residues, are composted. The liquid organic fraction from the urban areas (i.e., excreta) is assumed to be either treated in a simple treatment plant (Diaz, 1998), or collected and treated in 'plants' in the city (for example: night soil composting, Cross and Strauss, 1985; Shuval et al., 1981; or co-composting Obeng and Wright, 1987). Treatment of urban wastes reduces the total amount of organic carbon by 40 to $60 \%$ (Table 3).

\section{Organic carbon fluxes in urban Tunja: Potential for rural areas}

Figure 3 shows the calculated carbon-fluxes for the Municipality of Tunja. ${ }^{1}$

The analysis shows four main results:

1) Total organic carbon input into arable soils is 3900

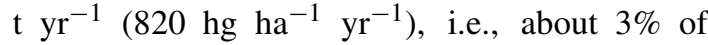
organic carbon stock.

2) Organic carbon self-supply of the rural area (3000

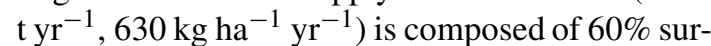
face plant residues, $37 \%$ decaying plant roots and

\footnotetext{
1 For details on the calculations and error margins please contact the first author.
} 


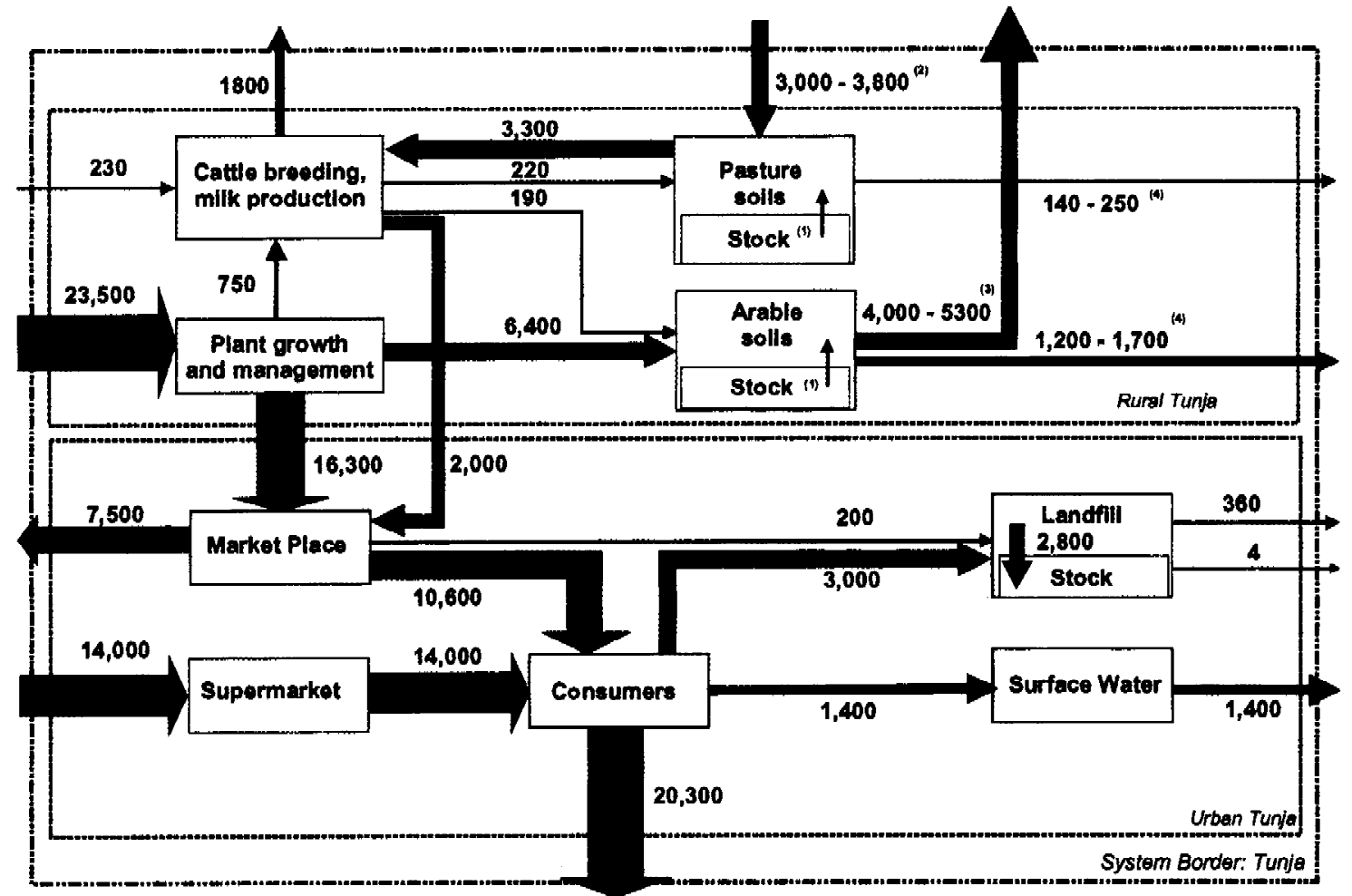

1: Organic matter in the stock could not be estimated due to lack of information

2: Rough net estimates of $\mathrm{CO}_{2}$ input (respiration from soil included)

3: Estimates concerning decomposition of organic residues one year after they were incorporated into the soil are based on Brady and Weil, (1996).

4: Estimates are based on different sources of organic matter to organic carbon content relationships.

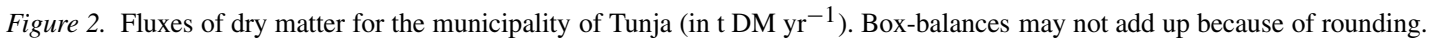

$3 \%$ cattle dung. It is about 3.5 times larger than the potential carbon input from treated organic wastes

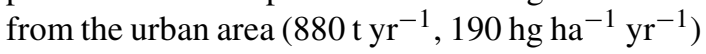
which could add a theoretical maximum of $30 \%$ to rural self-supply.

3) The potential contribution of urban areas is in the same range as the estimated C-losses through erosion (at $700 \mathrm{t} \mathrm{yr}^{-1}, 15 \mathrm{t} \mathrm{yr}^{-1} \mathrm{ha}^{-1}$ ). Thus, carbon from organic wastes from urban areas could in the short term compensate quantitatively for the loss of organic matter in arable soils from erosion. However, to fully evaluate the use of organic matter from urban in rural areas, quality criteria and biochemical dynamics must be included.

4) The C-flux from soils to the atmosphere (almost all in the form of $\mathrm{CO}_{2}$ ) is the biggest output flux. Thus, it largely determines the organic carbon balance in soils. At the same time, it is the most dynamic and uncertain flux in the whole system.
Effect of organic waste application on soil organic matter

The total potentially available organic carbon (including rural wastes) for the whole agricultural area is $820 \mathrm{~kg} \mathrm{C} \mathrm{ha}^{-1} \mathrm{yr}^{-1}$ (Table 4). Organic wastes from rural areas account for $630 \mathrm{~kg} \mathrm{C} \mathrm{ha}^{-1} \mathrm{yr}^{-1}$ (roots included), the potential input from urban areas is 190 $\mathrm{kg} \mathrm{C} \mathrm{ha}^{-1} \mathrm{yr}^{-1}$. Accounting for losses during urban waste collection and distribution of about $50 \%$ (Gorraiz, 1988, 50\% for Tunja; 50\% losses for Kumasi in Ghana, Leitzinger, 2000) the realistic annual organic carbon flux to arable soils lies at $730 \mathrm{~kg} \mathrm{C} \mathrm{ha}^{-1} \mathrm{yr}^{-1}$ (Table 4). Hence, there would be an average input increase of $15 \%$ by urban wastes, compared with rural self-supply. This corresponds to about $8 \mathrm{tha}^{-1} \mathrm{yr}^{-1}$ wet weight, assuming $45 \% \mathrm{C}$ content in dry weight and $80 \%$ water content in waste. If this amount were incorporated into the upper $20 \mathrm{~cm}$ of soil, in the short 


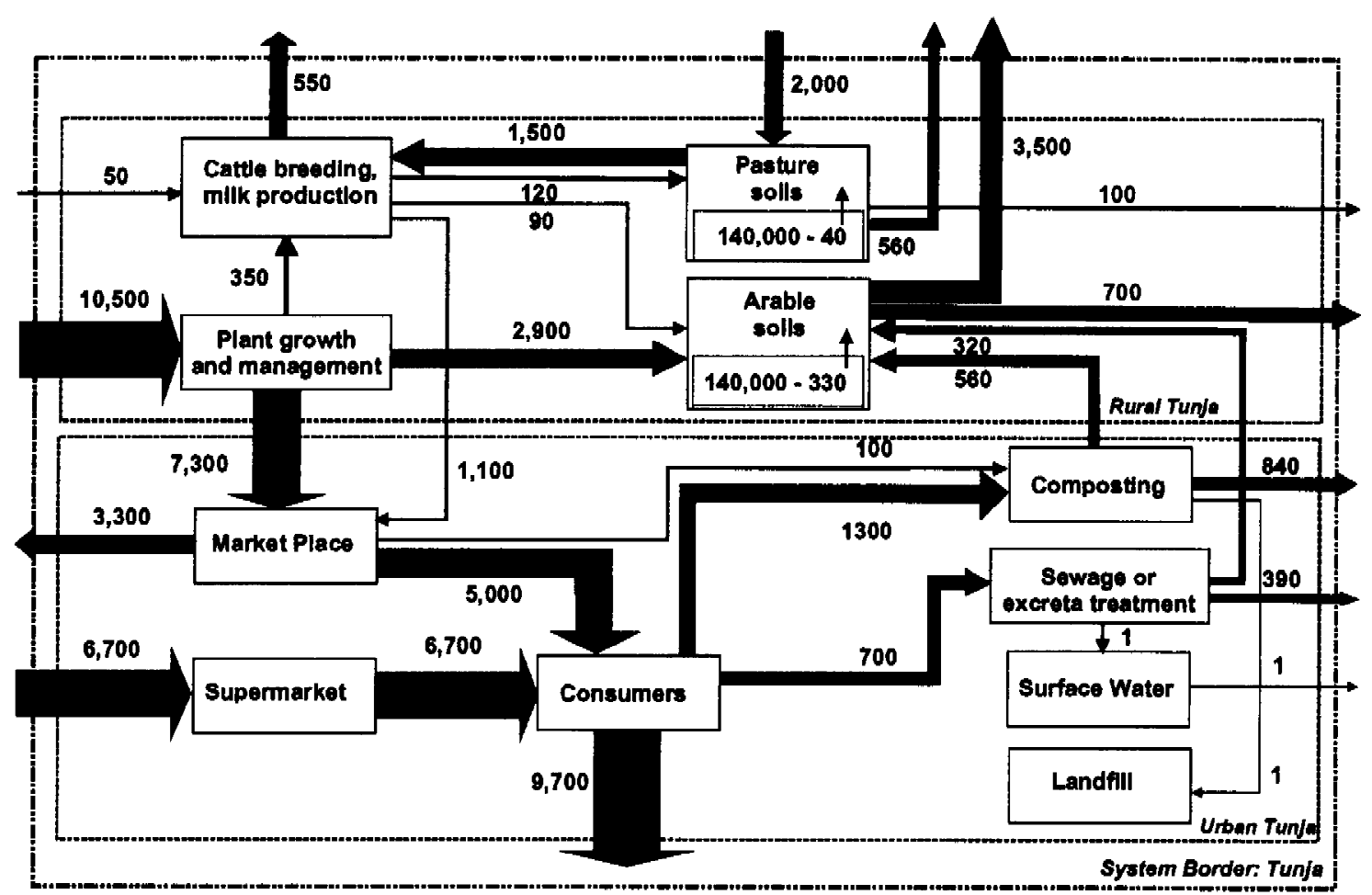

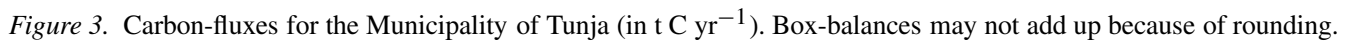

Table 3. Organic carbon in residues after different treatments of urban organic wastes

\begin{tabular}{|c|c|}
\hline Practice & Corg. in residue \\
\hline \multicolumn{2}{|c|}{ Solid organic waste treatment } \\
\hline Composting ${ }^{1}$ & $40 \%$ \\
\hline \multicolumn{2}{|l|}{ Excreta treatment ${ }^{2}$} \\
\hline Sewage treatment ${ }^{3}$ & $30-35 \%$ \\
\hline Night-soil composting 4 & $50 \%$ \\
\hline Co-composting 5 & $50 \%$ \\
\hline
\end{tabular}

${ }^{1}$ Following Obrist (1987).

${ }^{2}$ Note that liquid organic wastes, i.e. excreta, have a completely different composition than solid wastes. Their nutrient concentration is higher and their organic carbon content lower. In addition, their water content is very high ranging up to $94 \%$ in the excreta mixture (Cross and Strauss, 1985; Rohrer and Geiger, 1998).

${ }^{3}$ UASBR: Upflow anaerobic sludge blanket reactor used in the study region (Draaijer, 1992; Diaz, 1998).

${ }^{4}$ Estimated after Shuval et al. (1981).

${ }^{5}$ Estimated after Obeng and Wright (1987). term the total $\mathrm{C}_{\text {org }}$ content in soils would increase by about $3 \%$.

Assuming that one year after the application still $10 \%$ of the total input of organic carbon remains in the soil, that equals $0.3 \%$ of total SOM. As shown in Figure 3, however, this potential increase is more than offset by the losses due to erosion. Hence, to achieve an even numerical balance of organic matter in the soil, either the input into soil has to be increased, or erosion has to be reduced (see below).

\section{Other effects of applying organic wastes to arable soils}

It is common knowledge that the application of organic wastes to arable soils can have other beneficial effects besides increasing SOM, such as decreasing erosion, improving the nutrient balance, and structural effects (Hu et al., 1997; Hunter et al., 1997; Shang and Thiessen, 1998). First MFA estimates for phosphorus (P) for the case of Tunja showed that urban organic waste could play an important role as $\mathrm{P}$ supplier. Specifically we find that (i) the P-input from urban organic wastes (mostly excreta) is about one order of magnitude larger than the P-input from rural wastes; (ii) The P-input from urban wastes is in the same range 
Table 4. Potential organic carbon fluxes from urban and rural organic wastes

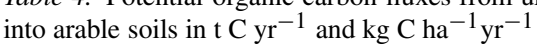

\begin{tabular}{|c|c|c|}
\hline & $\begin{array}{l}\text { Carbon fluxes into } \\
\text { arable soils ( } \mathrm{C}^{-1} \text { ) }\end{array}$ & $\begin{array}{l}\text { Carbon fluxes into arable } \\
\text { soils }\left(\mathrm{kg} \mathrm{C} \mathrm{ha}^{-1} \mathrm{yr}^{-1}\right) \\
\text { Max (Realistic) }\end{array}$ \\
\hline \multicolumn{3}{|l|}{ Urban Area: } \\
\hline Compost & 560 & $120(60)$ \\
\hline Treated excreta ${ }^{2}$ & 320 & $68(34)$ \\
\hline \multicolumn{3}{|l|}{ Rural Area: } \\
\hline Plant residues ${ }^{3}$ & 1760 & 370 \\
\hline Plant roots & 1100 & 230 \\
\hline Animal dung 4 & 120 & 26 \\
\hline Total & 3900 & $820(730)$ \\
\hline \multicolumn{3}{|c|}{$\begin{array}{l}{ }^{1} \text { We assumed } 50 \% \text { losses of organic matter during collection, treatment and } \\
\text { distribution of the wastes (Gorraiz, } 1988 \text {; Leitzinger, 2000). } \\
{ }^{2} \text { We assumed that about } 55 \% \text { of the } \mathrm{C} \text { in excreta are transformed to } \mathrm{CO}_{2} \text { or } \\
\mathrm{CH}_{4} \text { before application to the field. } \\
{ }^{3} \mathrm{We} \text { assumed that only the parts of the crop sold leave the field. Alba Gonzales } \\
\text { et al. (1998) found that } 16 \% \text { of plant residues were collected and used as food } \\
\text { for pigs and other animals. } \\
{ }^{4} \text { Value refers to untreated dung. }\end{array}$} \\
\hline
\end{tabular}

than the amount of $\mathrm{P}$ taken up by plants (see also Leitzinger, 2000).

\section{Scenario and sensitivity analysis}

Sensitivity and scenario analyses are applied to explore a model and create hypotheses about the investigated system. The influence of different parameters on key variables is examined. The scenarios are built on 'realistic benchmark assumptions'. In the following we discuss the sensitivity of organic carbon content in soils to changes in (i) input fluxes, (ii) the transfercoefficient defining the flux from arable soils to the atmosphere and (iii) the erosion rate.

\section{Input to arable soils}

We selected the following improvements with respect to the 'realistic scenario': Waste collection in the city is increased from 50 to $75 \%$, the wastes are treated and applied without losses to the fields. Plant residues are left completely on the fields, and animal dung is collected, treated and applied at $60 \%$ of the total amount produced. Following these improvements, the total flux of organic carbon into arable soils would increase by about $20 \%$. The costs for achieving this purpose, however, might exceed the potential gains.

The effect of organic matter input into a selected part of the arable soils could also be enhanced by supplying only part of the rural area with urban organic wastes. That is normal practice in tropical agriculture: Sites with higher productivity and closer to the settlements are managed more intensively than others, in order to improve structure and nutrient status (Scoones and Toulmin, 1998). If we assume, for the case of Tunja, that all the wastes from urban areas are applied to $20 \%$ of the arable land this would lead to an increase in the input flux per unit area of $100 \%$. This input flux would also correspond to the one recommended by the World Bank (Shuval et al., 1981; Obeng and Wright, 1987) and to the ones where increases in soil organic matter were observed over time (Khaleel et al., 1981).

With respect to the accessibility of the areas from the city, however, there is a trade-off between allocation needs (highest for poor small-holders on hillside areas) and allocation costs (highest for hillside farmers, and lowest for larger farms located on flat lands).

Transfer-coefficient defining the flux from arable soils to atmosphere

The transfer-coefficient defining the flux from arable soils to atmosphere has a significant influence on the $\mathrm{C}$-stock changes in soil. In addition, it is the most uncertain parameter in the system. Its drivers are decomposition and humification processes.

Table 5 shows the effect of changes in this transfercoefficient on the carbon stock in soils. If we assume 
Table 5. Sensitivity of changes in carbon stock in arable soils in function of changes in transfer-coefficient arable soils to atmosphere, input scenarios and erosion $\left(\mathrm{kg} \mathrm{C} \mathrm{yr}^{-1}\right)$

\begin{tabular}{|c|c|c|c|c|c|}
\hline \multirow{3}{*}{$\begin{array}{l}\text { Transfer-coefficient: } \\
\text { Arable soils to atmosphere }\end{array}$} & \multirow{3}{*}{$\begin{array}{l}\text { Current state }^{1} \\
\mathrm{Kg} \mathrm{C}\end{array}$} & \multirow{2}{*}{\multicolumn{2}{|c|}{$\begin{array}{l}\text { Realistic scenario }^{2} \\
\mathrm{Kg} \mathrm{C} \text { in arable soils }\end{array}$}} & \multirow{2}{*}{\multicolumn{2}{|c|}{$\begin{array}{l}\text { Best case scenario }{ }^{3} \\
\mathrm{Kg} \mathrm{C} \text { in arable soils }\end{array}$}} \\
\hline & & & & & \\
\hline & & Erosion & No erosion & Erosion & No erosion \\
\hline 0.95 & -550 & -530 & 170 & -490 & 210 \\
\hline 0.9 & -400 & -360 & 340 & -280 & 420 \\
\hline 0.85 & -253 & -190 & 410 & -70 & 630 \\
\hline 0.8 & -100 & 20 & 680 & 140 & 840 \\
\hline
\end{tabular}

that only 80 instead of $90 \%$ (conservative assumption in the general analysis) of the organic matter in soils were decomposed within one year, the carbon stock in arable soils would remain constant in the 'realistic scenario' and would increase in the 'best case scenario'.

The type of residue, climate and soil properties are important parameters influencing the dynamics of decomposition and humification processes.

Type of residue. The type of residue plays an important role during the first 60 days of the decomposition process. For fresh grass leaves, Weeraratna and Ashgar (1990) showed that under hot-moist tropical conditions, the decomposition process takes about 12 weeks.

For compost, sewage sludge and treated night soil the decomposition rate is lower than for incorporated plant residues (e.g., Kirchmann and Bernal, 1997), because compost is a product of decomposition and humification processes. During the composting process the easily digestible fraction of the organic components $(60 \%$ of total $\mathrm{C})$ is digested and a humin and lignin-rich compost is generated, with a water content of around 50\% (Obrist, 1987). For sewage sludge and treated night soil, Kirchmann \& Bernal (1997) found similar decomposition dynamics during the first 60 days than for compost.

Climate and soil type. Our study area lies in the highland tropics. In the lowland tropics, climate and soil conditions are different. We would expect, e.g., a Ferralsol (Oxisol) instead of the Cambisol (Inceptisol) of our area. Ferralsols dominate the wet lowland tropics of South America and Africa. They are old, deeply weathered soils with prominent occurrence of oxides and hydroxides from $\mathrm{Fe}, \mathrm{Al}$ and $\mathrm{Mn}$. The climate of such a lowland site is usually hot with heavy rainy seasons. That implies faster decomposition rates (Jenkinson and Anayba, 1977; Tiessen et al., 1994; Gijsman et al., 1997; Shang and Tiessen, 1997). Indeed, for plant material decomposition the $\mathrm{Q}_{10}$ (the change in the rate of reaction for each $10^{\circ} \mathrm{C}$ change in temperature) averages 2.6 for temperatures from $12.5^{\circ} \mathrm{C}$ to $40{ }^{\circ} \mathrm{C}$ (Nyhan, 1976). As the decomposition rates for organic matter in the lowland tropics are higher, additional OM input is even more important for these weathered, old soils under hot-moist conditions than in the Tunja case, to counteract the negative effects of SOM loss and low OM level.

\section{Erosion rate}

Table 5 shows the modeled effect of cessation of erosion. In the absence of erosion, in the 'realistic input scenario' the input would be sufficient to increase the organic matter level in soils, even if high decomposition rates are assumed. Thus, erosion conservation measures are complementary to increasing input of soil organic matter to soils. Application of organic matter to soils by itself could also contribute to lower erosion.

\section{Conclusions}

1. In the Municipality of Tunja, with an arable area of $47 \mathrm{~km}^{2}$ and 114,000 inhabitants, the potential for supplying agricultural soils with organic material is largest for organic residues produced in the rural areas itself. Currently, about $60 \%$ of 
the supply consists of surface plant residues, $37 \%$ of decaying roots, and $3 \%$ of cattle dung. The products from urban organic wastes are calculated to contribute an additional potential $30 \%$ to the total current rural $\mathrm{C}_{\text {org }}$-flux into arable soils; with realistic assumptions, half of that potential could be realized.

2. The analysis shows that for preserving or restoring the organic carbon content in the soils of Tunja, effective options are erosion control and increased input of organic matter to soils by using treated urban organic wastes. The latter should be concentrated to $1 / 5$ of the agricultural area, if an increase in soil organic matter is intended; hence, areas should be selected. Thereby, one has to consider that there could be a trade off between allocation needs and allocation costs. Additionally, the acceptance of wastes as fertilizers would have to be investigated.

\section{Acknowledgements}

We thank two anonymous reviewers for their excellent comments and contributions.

\section{References}

Alba Gonzales RE, Alvarado Gonzales OF, Rojas Gil LJ \& Ruiz Garcia SA (1998) Analysis de Flujo de Materiales para la Zona Rural del Centro del Departamento de Boyaca. Facultad de Ciencias e Ingenieria. Tunja, Fundacion Universitaria de Boyaca Aliva Neira YS \& Rincon Suarez HA (1998) Aplicacion del Modelo EPIC para la Determinacion de Fosforo como Consecuencia de los Procesos de Erosion y Escurrimiento de la Zona Rural del Centro del Departamento de Boyaca Facultad de Ciencias e Ingenieria. Tunja, Fundacion Universitaria de Boyaca

Anjos LH, Fernandes MR, Pereira MG \& Franzmeier DP (1998) Landscape and Pedogenesis of an Oxisol-Inceptisol-Ultisol Sequence in Southeastern Brazil. Soil Sci Soc Am J 62: 1651-1658

Baccini P \& Brunner P (1991) Metabolism of the Anthroposphere. New York, Springer

Baccini P \& Von Steiger B (1993) Die Stoffbilanzierung landwirtschaftlicher Böden-Eine Methode zur Früherkennung von Bodenveränderungen. Z Pflanzenernähr Bodenk 156: 45-54

Baccini P \& Bader H-P (1996) Regionaler Stoffhaushalt. Erfassung, Bewertung und Steuerung. Heidelberg, Spektrum Akademischer Verlag

Binder C (1996) The Early Recognition of the Environmental Effect of Human Activities in Developing Countries. PhD Thesis, Department of Resource and Waste Management. Swiss Federal Institute of Technology, Zürich

Binder C, Schertenleib R, Diaz J \& Baccini P (1997) Regional water balance as a tool for water management in developing countries. Water Res Manag 13: 5-20
Bosch Hvd, De Jaeger A \& Vlaming J (1998) Monitoring nutrient flows and economic performance in African farming systems (NUTMON) II. Tool development. Agric Ecosyst Environ 71: 49-62

Bormann FH \& Likens GE (1969) The watershed-ecosystem concept and studies of nutrient cycles. In: Van Dyne GM (ed) The Natural Resource Ecosystem, pp. 49-76. New York, London: Academic Press

Brady NC, Weil RR (1996) The Nature and Properties of Soils, New Jersey: Prentice-Hall Inc

Cross P \& Strauss M (1985) Health Aspects of Nightsoil and Sludge Use in Agriculture and Aquaculture. Dübendorf, International Centre for Waste Disposal (IRCWD)

DANE (1994) Censo 1993. Bogota: DANE

Diaz J (1998) Tratamiento de Aguas Residuales Domesticas del Municipio de Tunja por medio de un reactor UASB de dos compartimientos operando en el rango psicrofilico de temperatura. Tunja, Fundacion Universitaria de Boyaca

Draaijer E (1992) Performance of the 5 MLD UASB reactor for sewage treatment at Kanpur, India. Water Sci Tech 25: 123-133

EAAT (1993) Statistics and personal communications, Javier Rodriguez. Tunja, Empresa de Acueducto y Alcantarillado Tunja

Gijsman AJ, Alarcon HF \& Thomas RJ (1997) Root decomposition in tropical grasses and legumes, as affected by soil texture and season. Soil Biol Biochem 29: 1443-1450

Gorraiz V (1988) Estudio Propuesta de Recolleccion, Tratamineto y Disposicion Optima de los Residuos Solidos para la Ciudad de Tunja. Facultad de Ciencias e Ingenieria. Tunja, Fundacion Universitaria de Boyaca

Graff O (1995) Geschichte der organischen Düngung: von Stercutus bis heute. Hamburg, Verlag Dr. Kovac

Haase R (1992) Physical and chemical properties of Savanna soils in Northern Bolivia. CATENA 19: 119-134

Hu S, Coleman DC, Carroll CR, Handrix PF \& Baere MH (1997) Labile soil carbon pools in subtropical forest and agricultural ecosystems as influenced by management practices and vegetation types. Agric Ecosyst Environ 65: 69-78

Hunter DJ, Yapa LGG \& Hue NV (1997) Effects of green manure and coral lime on corn growth and chemical properties of an acid Oxisol in Western Samoa. Biol Fertil Soils 24: 266-273

Jenkinson DS \& Anayaba A (1977) Decomposition of carbon-14 labeled plant material under tropical conditions. Soil Sci Soc Am J 41: 921-915

Khaleel R, Reddy RK \& Overcash MR (1981) Changes in soil physical properties due to organic waste applications: A Review. J Environ Qual 10: 133-141

Kirchmann H \& Bernal MP (1997) Organic waste treatment and C stabilization efficiency. Soil Biol Biochem 29: 1747-1753

Leitzinger $\mathrm{CH}$ (2000) Ist eine Co-compostierung aus stofflicher Sicht in Kumasi/Ghana sinnvoll? Diploma Thesis, Swiss Federal Institute of Technology, Zürich

Lindeman RL (1942) The trophic-dynamic aspect of ecology. Ecology 23: 399-418

Lynam JK, Nandwa SM \& Smaling EMA (1998) Nutrient balances as indicators of productivity and sustainability in sub-saharan agriculture. Introduction to the Special Issue. Agric Ecosyst Environ 71: 1-4

Müller DB, Oehler D \& Baccini P (1995) Regionale Bewirtschaftung von Biomasse; Eine stoffliche und energetische Beurteilung der Nutzung von Agrarflächen mit Energiepflanzen. vdf Zürich

Nandwa SM \& Bekunda MA (1998) Research on nutrient flows and balances in East and Southern Africa: state-of-the-art. Agric Ecosyst Environ 71: 5-18 
Nyhan JW (1976) Influence of soil temperature and water tension on the decomposition rate of carbon-14 labeled herbage. Soil Sci 121: 288-293

Odum HT (1955) Time's speed regulator: the optimum efficiency for maximum power output in physical and biological systems. Am Sci 43: 331-343

Obeng LA \& Wright FW (1987) Integrated Resource Recovery: The Co-composting of Domestic Solid and Human Wastes. Washington, DC: The World Bank

Obrist W (1987) Material balance of the composting process. BioCycle 28: 32-33

Pagliai M \& Antisari VL (1993) Influence of waste organic matter on soil micro- and macrostructure. Biores Tech 43: 205-213

Pascual JA, T Hernandez, Garcia C \& Ayuso M (1998) Carbon mineralization in an arid soil amended with organic wastes of varying degree of stability. Commun Soil Sci Plant Anal 29: 835-846

Recktenwald HC \& Samuelson PA (1986) Thünen - ein Klassiker in unserer Zeit. Mainz: Franz Steiner Verlag

Rohrer T \& Geiger M (1998) Komposttoiletten-Information für die Praxis. Steinhuserberg, Zentrum für Angewandte Oekologie Schattweid

Samuelson PA (1987) Thünen nach 200 Jahren. Eine moderne Würdigung. Thünen - ein Klassiker unserer Zeit. H. C. Recktenwald, Samuelson, P.A. Wiesbaden und Stuttgart, Akademie der Wissenschaften und der Literatur, Mainz: 25-69

Scoones I \& Toulmin C (1998) Soil nutrient balances: what use for policy? Agric Ecosyst Environ 71: 255-267

Shang C \& Tiessen H (1997) Organic matter lability in a tropical Oxisol: Evidence from shifting cultivation, chemical oxidation, particle size, density, and magnetic fractionations. Soil Science (USA) 162: 795-807

Shang C \& Tiessen H (1998) Organic matter stabilization in two semiarid tropical soils: Size, density, and magnetic Separations. Soil Sci Soc Am J 62: 1247-1247

Shuval HI, Gunnerson CG \& Julius DAS (1981) Appropriate Technology for Water Supply and Sanitation: Night Soil Composting. Washington, DC: The World Bank

Sheperd KD \& Soule MJ (1998) Soil fertility management in west Kenya: dynamic simulation of productivity, profitability and sustainability at different resources endowment levels. Agric Ecosyst Environ 71: 131-145

Stoorvogel JJ \& Smaling EMA (1990) Assessment of soil nutrient depletion in Sub-Saharan Africa: 1983-2000. Volume I: Main report. Report 28. The Winand Staring Centre, Wageningen

Von Thünen JH (1826) Der isolierte Staat in Beziehung auf Landwirtschaft und Nationalökonomie. Untersuchungen über den Einfluss, den die Getreidepreise, der Reichtum des Bodens und die Abgaben auf den Ackerbau ausüben. Hamburg

Tiessen H, Cuevas E \& Chacon P (1994) The role of soil organic matter stability in soil fertility and agricultural potential. Nature 371: 783-785

URPA (1995) Diagnóstico Agropecuario de Boyacá. Tunja, Ministerio de Agricultura y Desarrollo Rural

Weeraratna CS \& Asghar M (1990) Effects of grass and mulches on some soil (an Inceptisol) properties and yield of taro (Colocasia esculenta) in Western Samoa. Trop Agriculture (Trinidad) 69: 83-86 